\title{
Circuit
}

Musiques contemporaines

\section{Ecclesiastes et Psychosoma (2015) : deux manuscrits inédits de John Zorn}

\section{François-Xavier Féron}

Volume 25, numéro 3, 2015

URI : https://id.erudit.org/iderudit/1034499ar

DOI : https://doi.org/10.7202/1034499ar

Aller au sommaire du numéro

Éditeur(s)

Les Presses de l’Université de Montréal

ISSN

1183-1693 (imprimé)

1488-9692 (numérique)

Découvrir la revue

Citer ce document

Féron, F.-X. (2015). Ecclesiastes et Psychosoma (2015) : deux manuscrits inédits de John Zorn. Circuit, 25(3), 75-77. https://doi.org/10.7202/1034499ar d'utilisation que vous pouvez consulter en ligne.

https://apropos.erudit.org/fr/usagers/politique-dutilisation/ 


\section{Ecclesiastes et Psychosoma (2015): deux manuscrits inédits de John Zorn}

Introduction de François-Xavier Féron

En 2006, Zorn réunit Mike Patton (voix), Trevor Dunn (basse) et Joey Baron (batterie) le temps d'un cycle de chansons sans paroles, définitivement hardcore. Moonchild, le titre de l'album, devient celui de cet incroyable trio autour duquel Zorn va finalement concevoir une septologie (encore le chiffre 7 !) qu'il achèvera en 2014 ${ }^{1}$. En 2015, Zorn crée dans le même esprit un nouveau power trio composé de John Medeski (orgue électrique), Matt Hollenberg (guitare) et Kenny Grohowski (batterie). C'est le début des aventures sonores de Simulacrum, trio avec lequel Zorn a enregistré pas moins de trois albums en une année seulement: Simulacrum, The True Discoveries Of Witches And Demons et Inferno ${ }^{2}$. Dans la suite logique du cycle réalisé avec Moonchild, Zorn n'hésite pas à enrichir le groupe (et ses compositions) en faisant appel à des musiciens supplémentaires. Ecclesiastes et Psychosoma sont deux morceaux tirés de l'album The True Discoveries Of Witches And Demons pour lequel le compositeur a fait appel au service de Marc Ribot (guitare) et Trevor Dunn (basse).

The True Discoveries of Witches and Demons is the second release by Zorn's heavy new organ trio of John Medeski, Matt Hollenberg and Kenny Grohowski. Described as Tony Williams' Lifetime on steroids, here they are joined by special guests Marc Ribot and Trevor Dunn to make the music even heavier and more intense. This is white hot, mind bending music filled with heavy riffs, fiery solos and improvisational madness. Three generations of musical explorers come together to rip your mind to shreds in the second installment from Zorn's heaviest new ensemble Simulacrum ${ }^{3}$.

Nous tenons à remercier très chaleureusement John Zorn pour nous avoir fourni gracieusement ces deux manuscrits inédits qui rendent compte de certaines caractéristiques essentielles de son langage musical: le recours à l'atonalité, une structuration rythmique complexe, ou encore la délimitation très précise des parties improvisées.

\author{
1. John Zorn, Moonchild, Songs Without \\ Words (TZ 7357, 2006), Astronome \\ (TZ 7359, 2006), Six Litanies for \\ Heliogabalus (TZ 7361, 2007), The \\ Crucible (TZ 7372, 2008), Ipsissimus \\ (TZ 7386, 2010), Templars - In Sacred \\ Blood (TZ 7398, 2012), The Last \\ Judgment (TZ 8325, 2014). \\ 2. John Zorn, Simulacrum (TZ 8330, \\ 2015), The True Discoveries Of Witches \\ And Demons (TZ 8335, 2015), Inferno \\ (TZ 8336, 2015).
}

3. <www.tzadik.com> (consulté le 15 septembre 2015). 


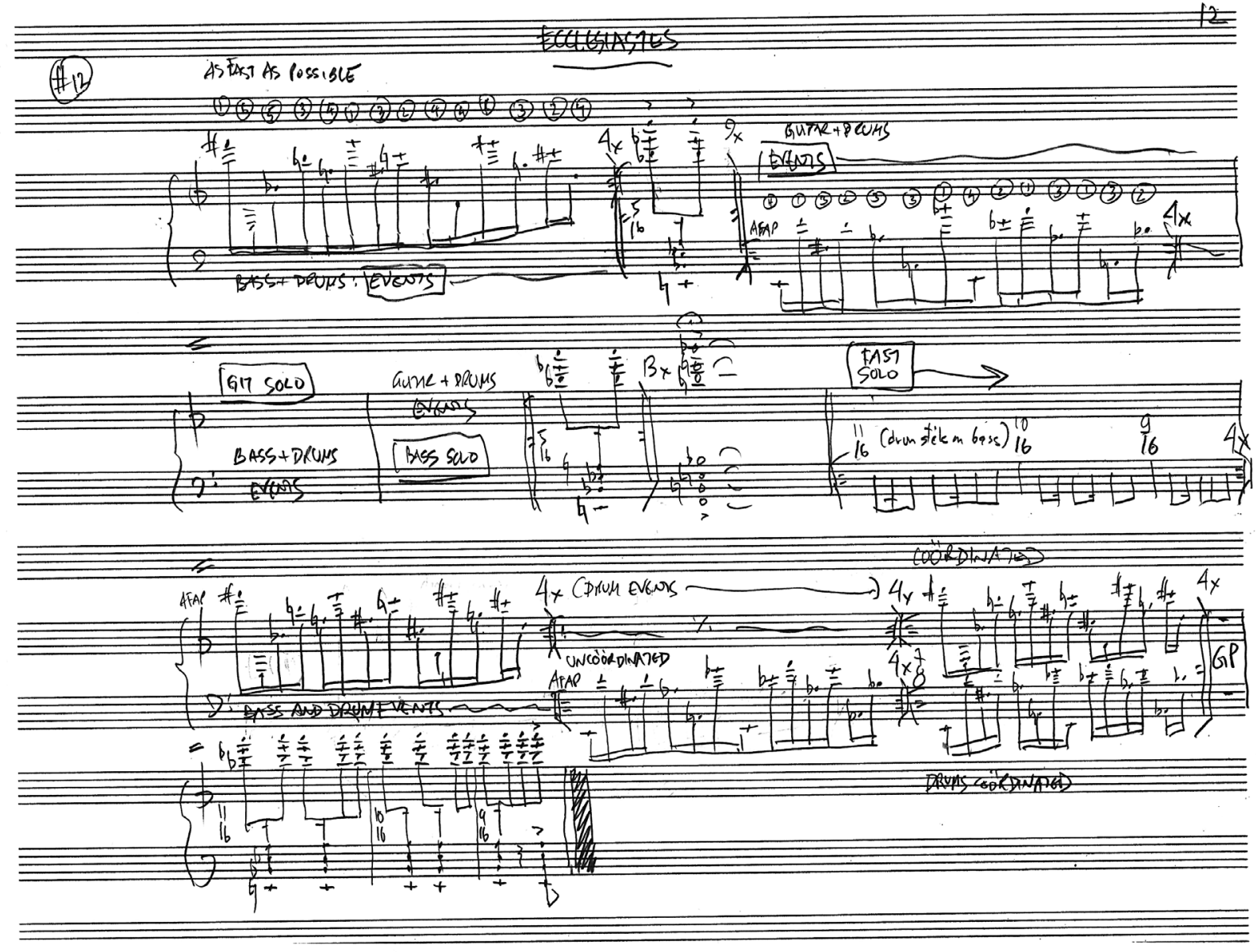




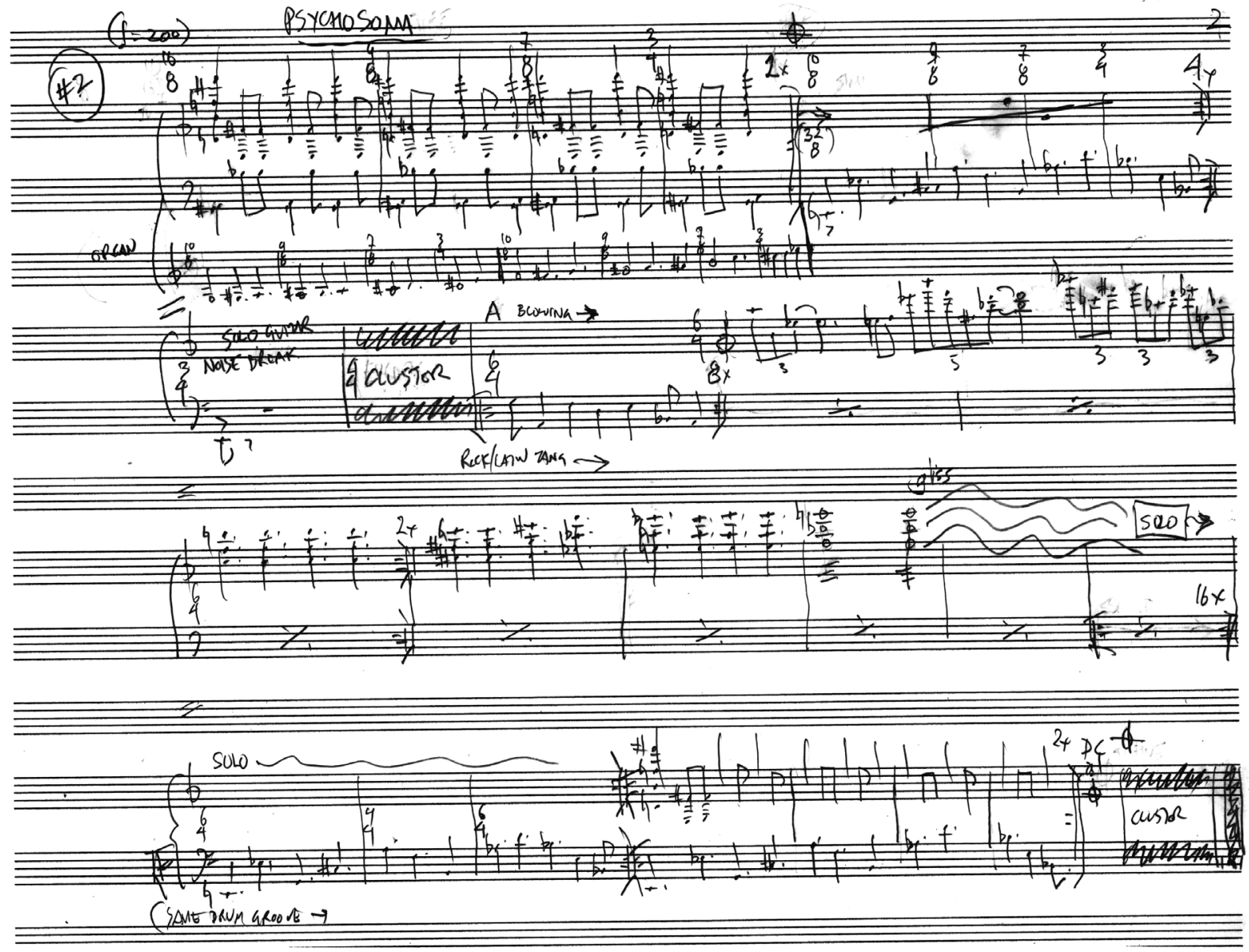

